\title{
The Application of Game-based Approach in Primary School English Teaching
}

\author{
Fengjuan Zhang \\ Zhengzhou University of Industrial Technology, Zhengzhou 451000, China
}

Keywords: game-based approach, English teaching in primary school, interest.

\begin{abstract}
This thesis regards game-based approach in primary school English teaching as the research object to make a study on English teaching approach in primary school about the character, the principles and the goals with many kinds of research methods. This thesis first introduces the background about game-based approach in primary school English teaching. Then it analyzes the definition, type and the characteristic of the game teaching method, and elaborates the game teaching method rationale. Finally, the article proposes the implementation of game teaching method in primary school English teaching. Through this thesis, the conclusion can be drawn that the game-based approach is containing the huge prospects for development in the elementary school English teaching.
\end{abstract}

\section{Introduction}

Playing games in English teaching is one of the effective ways to motivate children to work hard and cultivate their interests in learning English. With the recent development of English teaching, the roles of games in class have been discussed in different aspects. And more and more teachers use games in their teaching as they come to realize that playing games in English teaching is very important.

Game-based approach is a kind of instructional activity, which integrates games into teaching for instructional goals. Through game-based approach, instructional goals achieved more easily. Under the teachers' guide, students can learn knowledge and improve abilities. So, game-based approach in English teaching is also an important instructional method, which is used in teaching English for purpose of stimulating students' learning interests and improving teaching effect. Someone points out that game-based approach in English teaching is playing dramatic conflict, in which students can master English knowledge and skills through interesting games. This one also states that game-based approach in English teaching should be dramatic, playable and instructional. Game-based approach aims at creating suitable context for students to learn and practice English with the application of interesting games and teamwork. According to other people, English game teaching refers to the method used by teachers in English instruction. However, there are some demerits of the game-based approach in its application.

This thesis is to provide the game-based teaching method for English teachers in primary school. Children enjoy playing games and prefer to acquire knowledge in a relaxed environment.

\section{Researches on English Game-Based Approach}

\subsection{Definition of Games}

The word "game" has been defined by many scholars and authorities. Spodek Bernard and Saracho Olivia demonstrated that: games are a different kind of play activities. They are highly structured and include specific rules to be followed. Similarly, Jill Hadfield defined games as "an activity with rules, a goal and an element of fun."

Byrne gave the definition to games as a form of play governed by rules. They should be enjoyed and fun. They are not just a diversion, a break from routine activities, but a way of getting the learner to use the language in the course of game. 


\subsection{Function and Goal of Games}

The basic function of games teaching can be described like these: exciting students' learning interest effectively, promoting the development of students' intelligence and training students' innovation ability [1].

\subsubsection{Interest in Learning a Foreign Language}

It's known that interest is an important and crucial factor to influence motivation in foreign language acquisition. Game-based approach in primary school English teaching does not only make the students joyful, but also make them full of wit and humor. It can excite the students' curiosity for the knowledge so that they will show interest in learning in class; in return, interest can contribute to academic success. Finally, interest and success become the great driving force for the students to learn English. Interest is the best teacher for children. Once children lose their interests in learning English, they couldn't lay a good foundation in basic knowledge. They cannot learn English well in the future.

The students need to involve in something active, so almost everything for them will depend on the creative attitude and behavior of teachers who must be technically adept at ways of getting the students motivated.

The intrinsic motivation to learn something is enhanced by the use of interesting materials, as well as by varieties in mode of presentation. Games add variation to a lesson and increase motivation by providing a plausible incentive to use the target language. For many children between four and twelve years old, especially the youngest, language learning will not be key motivational factor. Games can provide this stimulus. Games automatically stimulate students' interests. Therefore, a properly introduced game can be one of the highest motivating techniques.

\subsubsection{Pleasure from Learning English}

Various kinds of language teaching games can be employed to make a lively and enlightening classroom. Games can make learning interesting and exciting, arouse the learning enthusiasm and offer opportunities for academic success. Games can make English classes more interesting and easier, so English learning will become a pleasure and English classroom will become a pleasant place. Confucius holds that happy learning not only makes one delight in learning, but also never makes one sick of learning.

\subsubsection{Meeting Children's Needs}

During students' growing, they have some needs. The games can create a suitable situation to meet children's needs: security, love, respect, and self-fulfillment so that students can find pleasure and self-confidence in such circumstance. It can not only help students grasp the language points, and light up the classroom, but also improve learners' interests in the long run.

\subsubsection{Creating a Stress-free Learning Environment}

A stress-free learning environment is vital for children to learn English. Games can help teachers enlighten their students to think actively, and encourage them to use their heads, eyes, mouths, hands more often, and can guide students to study voluntarily and can arouse students' desire for using foreign language to express their ideas and feelings. Thus their comprehension and expression abilities in foreign language can be well developed.

\subsection{Advantages of Games}

Language learning is a hard work. Games can help and encourage many learners to sustain their interests. They play an important role in language teaching. Here are many valid reasons for using games in language teaching, including effective reasons, cognitive reasons and linguistic reasons. These reasons provide insights into the advantages of games in language teaching.

Penny Ur [4] commented that games were using both visual and aural channels as well as activating language production and advocated physical movement. Game-based teaching has had numerous advocates. John Locke claimed games were integral to schooling since they provided active and positive learning experience. George Herbert Mead, a colleague of Dewey's, acknowledged their importance for the healthy socialization of children. Through games, children 
learned to imitate and assumed diverse social roles. Certainly, Jean Piaget stressed the importance of game-playing in cognitive development.

Games are fun and children like to play games. The game context makes the foreign language useful to the children. It brings the target language to life. Through playing games, students can learn English the way children learn their mother tongue without realizing they are learning; thus without stress, they can learn a lot, even shy students can participate positively.

\subsection{Types of Games}

Classifying games into categories can be difficult, because categories often overlap. Hadfield explains two ways of classifying games. First, he divides language games into two types: linguistic games and communicative games. Linguistic games focus on accuracy, such as supplying the correct antonym. Besides, communicative games focus on successful exchange of information and ideas, such as, two people identifying the differences between their two pictures which are similar to one another but not exactly alike. Correct language usage, though still important, is secondary to achieving the communicative goal.

Besides, there are plenty of ways to practice listening, speaking, reading and writing with games. In order to make students take part in playing games, it is very important to enrich the variety of games, even the most interesting game will not be interesting when it is played frequently.

\section{Application of Game-Based Approach in Primary School English Teaching}

Games can play a range of roles in the language curriculum. Traditionally, games have been used in the language class as warm-up at the beginning of class, fill-ins when there is extra time near the end of class, or as an occasional bit of spice stirred into the curriculum to add variety. All these are fine, but games can also constitute a more substantial part of language course. In the Presentation-Practice-Production framework, the games can be either for practicing specific language items or for more communicative output of language. Similarly, games can also be used as a way to revise and recycle previously taught language.

Besides, there are some tips about how to use games in language teaching.

\subsection{Choosing Appropriate Games}

When choosing a game, the teacher should be careful to find an appropriate one for the class in terms of language and type of participation. There are a great number of language games. So teachers have a variety of participation. There are a great number of language games. So teachers have a variety of choices. However, in deciding which game to be used in a particular class and which game will be most appropriate and most successful with their students, teachers must take many factors into account.

According to previous researches, teachers should consider students' characteristics: whether they are old or young, serious-minded or light-hearted, and highly motivated to learn or not. They should also consider when the game should be used because there is a big difference between using the game in the morning or in the afternoon, on Monday or Friday.

In addition, teachers should be able to play and overact sometimes to help students feel comfortable and want to join the activity. This means teachers should thoroughly understand the game and its objective and be able to lead the game.

It is quite difficult to find a game that meets all of the teachers' requirements. Some games must be adopted in order to fit students' language level, natures and characteristics. The most important factor is that games should be used when they can give students both fun and education otherwise they will be a waste of time.

\subsection{The Integration of Games into Learning}

Games should be regarded as an important part of an English lesson, but the whole syllabus should not be based on games only even for young learners. Remember that a game for a game's sake is not good. The teacher should choose a game that will let them practice their target language. 
"There is a common perception that all learning should be serious and solemn in nature and that if one is having fun and there is hilarity and laughter, then it is not really learning. This is a misconception. It is possible to learn a language as well as enjoy oneself at the same time”.

In the traditional classroom, there is an assumption that the teacher should explain or do some kinds of pattern practices before the children play a game. Games are not "real" study. When an exam is coming, or a unit of a textbook has to be finished, it is the games that are dropped. The teacher will say there is no time to have fun. In many less traditional classes, games do play a central role. They are often not integrated into a professionally planned course. Typically, the children play games like bingo, and "enjoy" playing with English. The activities tend to be selected because they are fun, and may be repeated over and over again even when their language content is no longer useful.

Some teachers recognize the limitation of the traditional method of "study" and the less traditional "let's-enjoy-English" approach, and try to combine the two. The games may be mainly for relief, or they may link more closely with the "study" sections.

This tendency is often said or implied by teachers. "If you don't stop talking, we won’t play bingo". Learning English then becomes something children feel they "have to" do, while playing games becomes something they "want to" do purely for the sake of it.

\subsection{Making Rules}

Unless the learners know what they expected to do and how to do it, the aim cannot be achieved and the game cannot be played, so the teachers should give clear rules as many as possible.

However, rules are always difficult to negotiate. That is why most teachers carefully plan the rules for the games they wish to play. Although rules are carefully planned, it seems to be universal that students love breaking some rules while playing. This breaking of the rules can also turn out to be extremely dangerous and harmful to the environment in the class for it may cause quarrels, especially among children. Students must be very aware of the importance of the game rules they are playing and there must be a kind of honor code or ground rules that participants must follow while playing. The understanding rules make $70 \%$ of a successful activity.

\subsection{Time Limitation}

Time limitation is important. What makes the game interesting depends on time. If a student spends a lot of time answering a question then the other students become bored and lose their interests. And when they become bored, as the old saying goes, "The devil finds work for idle hands". There are different ways of setting time limits. Some teachers like to use an "egg timer" or similar device and other teachers just "count to three" in their hands. The main drawback of these methods is that they don't allow students to interact in any form.

The huge advantage in this system is that it gives the teacher a lot of flexibility in the amount of time actually given. The quicker students can have the challenge of a quick countdown and the slower students can get a bit of extra time to answer the question. This may seems to be a little unfair at first glance, but the students seem to understand and appreciate the idea. If the game gets really exciting, the teacher doesn't have to count. The students will participate the games happily, and what the teachers have to do is show the fingers. Depending on the length of the answers, the teacher can also vary the time taken.

\subsection{Rewards and Penalties}

If a student fails to answer the question or can't finish a game successfully within the allowed time, they must stand up. They can get a chance to "win back" their right to sit down on the next round. If a student does it well, he should be praised or given some rewards.

Sometimes, learners get fed up at night if they lose a game or other learners might tease the loser, in this case the teacher must teach the kids the golden miles of games. Losing doesn't mean failure. The real meaning of the word is that you can get another chance to try again. You never fail until you stop trying. If everyone is having fun, everyone is a winner. If they don't win, it is simply another chance to try again next time. Do this and every learner will want to keep going and learn more, especially if they actually lose a game. 


\subsection{Varying the Games}

Games should be rich and varied so that children won't be tired or bored. As is known, the best games cannot be played for a long time. Students like to play something new or different.

Teachers should frequently collect or create games. Teachers should always name the games. Make the names short and easy to remember. The game itself is not the language lesson. For example, if the teacher wants to play Snakes and Ladders, just call it Snakes.

In addition, once the game has begun, the teacher should not interrupt to correct some mistakes in language use.

\section{Conclusion}

The aim of this thesis is to draw people's attention to game teaching in primary school, and it's more effective than a traditional classroom by using games. The previous researches also approve that game-based approach is good for students' English speaking and reading competence, because games with their experiential and motivational features provide a vehicle to engage students in conversations and teach them conversational skills. Additionally, games can solve the problem about lack of authentic conversation strategies in textbooks. Besides, the context of reading class revealed that the majority of the lesson time was devoted to general management and a full-game environment can be quite beneficial.

Since teaching is a development art, which requires innovative and creative ideas to enrich its effectiveness. The teachers should be decisive to use games in their classrooms. Games can assist them in foreign language teaching and stimulate students' interest by providing a relaxed atmosphere. Such games take the student as a center. Hence, by using them, the teachers give a chance to their students to express themselves and enjoy themselves during learning. So there is an undeniable fact that if the teachers' concern is to provide a successful and beneficial teaching, they must not hesitate to use games, which bring the structural, pragmatic, prosodic and communicative aspects of language together in their classroom. Playing games in English teaching is one of the effective ways which are suitable for the development of children's physiological and physiological characteristics and can foster their interest and generate their thirst for knowledge. In the course of playing games, children take an active part in the games with the great interest, enjoy the pleasure and happiness of learning and have a sense of achievement.

In a word, it is found that the game-based approach does help the primary students to learn English better, thus become an effective teaching approach for primary school teachers. However, there are still some problems existing in the application of game-based approach. Game-based approach should focus on pupils' interests. Any kind of game-based approach is designed for purpose of attracting pupils' attention and arousing their interest in learning English. Therefore, English teachers should use appropriate games in teaching. Taking pupils as the center, game-based approach should be prepared carefully in advance. Well-designed teaching games are an effective teaching form. A too easy or too difficult game is bad for realizing instructional goals.

By analyzing the previous researches, the author makes a conclusion that the reason for primary school students failing to do well in the classroom games is that teachers and students spend too much time on the theological preparations or other activities. In the game-based approach classes, teachers allocate more time in playing games, spending less time on writing practice. Much more important, it is a little difficult for primary school English teacher to design the game-based approach, because this approach is hard to be made systematically. If this problem is to be solved, the game-based approach or an interactive teaching approach might be better. At the same time, after the study, it is found that the game-based approach does help the pupils learn English better, and it is an effective teaching approach in primary school English teaching.

However, the present researches on game-based approach in primary school English teaching do have a few limitations. For example, the present study does not consider the detailed organization of games in primary school English classes. This does not mean that the organization of games is not important. Actually, it can be the key to the success of game-based approach. So, researches on the 
organization of in-class games can be a new topic. Therefore, different perspectives of study can be carried out. Besides, it is not easy to achieve the positive functions of game-based approach in primary school English teaching. Limited by the time, conditions and the author's abilities, the results and findings of the current study are not enough. In this thesis, it is the first time for the author to conduct a research on game-based approach in primary school English teaching, so the personal experience and abilities would limit the study in some degree. However, the author hopes that the study on game-based approach in primary school English teaching instruction can be developed further, and gives some suggestions for future researches.

Firstly, game-based approach should focus on pupils' interests. Different with games in life, the games in English instruction are all used for educational purposes. Any kind of game teaching is designed for attracting pupils' attention and arousing their interests in learning English. Therefore, teachers should choose appropriate games to teach pupils English based on their interests. Owing to that, pupils will have strong motivation to learn English through interesting games. As a result of that, pupils can master the English knowledge and enhance their communicative abilities easier.

Secondly, game-based approach should take pupils as the center. This principle puts students in the center of class education. It does not weaken the instructional function of teachers, but highlights their guiding and evaluating status in class education. Teachers help pupils to acquire basic language knowledge and practical skills and evaluate their learning process towards educational objectives. For pupils, they take part in the learning process and develop abilities and skills through flexible and variable games by teachers. In the meantime, teachers should take students' interests and contemporary literacy into account. Games should follow the principles of focusing students' interests. Different games apply to different ages of learners. Their difficulty should be suitable for their ages and contemporary literacy. Oversimplified and overcomplicated games are unwise to be chosen for students. They cannot take effect on learning and easily cause counteraction.

Thirdly, game-based approach should be prepared carefully in advance. Well-designed teaching games are an effective teaching form. In order to realize the expected educational aims, teachers should make a sufficient preparation. First of all, teachers should remember the purpose of using games in class, choose the proper teaching games and select suitable time to use them in a flexible way. Moreover, games should be multi-leveled or should be in the hierarchy of difficulty. Too easy or too difficult games are bad for realizing instructional goals. Different games should be played for corresponding purpose, for mechanical practical purpose, or for language communication purpose. Then, teachers should encourage all the students to take part in the games in order to let all of them experience the success and keep their enthusiasm in learning. Finally, the organization of games is quite important. Teachers should take charge of the whole process of game playing and make sure the procedure go smoothly as well as the rhyme of playing is moderate.

\section{References}

[1]. Dessri, Angkana. Teaching and learning in the Language Classroom. Shanghai Foreign Language Education Press, 2002, p. 31-36.

[2]. Kodotchigova, Maria A. Role Play in Teaching Culture: Six Quick Steps for Classroom Implementation. Cambridge University Press, 2002, p. 101-103.

[3]. Lee, Su Kim. The Biological Foundations of Language. John Wiley and Sons, 2005, p. 122-124.

[4]. Penny, Ur. A Course in Language Teaching: Practice and Theory. Foreign Language Teaching and Research Press, 2010, p. 131-136.

[5]. Plato. Laws. Oxford University Press, 2009, p. 57-60.

[6]. Rousseau, Jean J. Émile, ou De l'éducation. People’s Education Press, 2001, p. 81-86.

[7]. Spodek, Bernard. \& Saracho, and Olivia N. Foundations of Early Childhood Education: Teaching Three-, Four-, and Five-year-old Children. Lawrence Erlbaum Associates Inc, 2005, p. 43-48. 